\title{
THE CURATIVE ROLE OF CURCUMIN AND FLAXSEED EXTRACTS IN MICE INOCULATED WITH EAC: BIOCHEMICAL AND HISTOLOGICAL STUDY
}

\author{
Osama M. Badr, Eman M. Shirefa, Omaima A. Khamis
}

Department of Animal Biotechnology, Genetic Engineering \& Biotechnology Institute, University of Sadat City, Sadat City, Minufiya Province, Egypt.

(Email: osama.badr@gebri.usc.edu.eg)

\begin{abstract}
This investigation discussed the role of curcumin and flaxseed in defeating induced solid tumours with the subcutaneous inoculation of mice with Ehrlich Ascites Carcinoma (EAC) in a definite volume ( $3 \times 10^{6}$ cells). Once the tumours were formed, the mice were divided into four groups (control, tumour untreated, curcumin and flaxseed) groups. Each group contains six mice. By the end of experimentation (28 days) after tumour formation, mice were dissected and histological examination for liver and kidney were performed in all groups. Also, the levels of liver functions (ALT \& AST), kidney functions (Urea \& Creatinine), oxidant and antioxidant enzymes (MDA, SOD and CAT) were measured in all tested groups. This study could state that Curcumin and flaxseed modulated the histological structures of both liver and kidney close to normal patterns. Also, treatments could modified the elevated values of (ALT, AST, Urea, Creatinine and MDA) and decreased levels of (SOD and (AT) towards the normal values. Treatments with Curcumin and flaxseed also reduced the tumour volumes significantly.
\end{abstract}

Key Words: Curcumin, flaxseed, liver, kidney, Ehrlich Ascites Carcinoma (EAC), solid tumour, alanine transaminase (ALT), aminotransferase (AST), urea, creatinine, malondialdehyde (MDA), superoxide dismutase (SOD) and catalase (CAT).

\section{INTRODUCTION}

Cancer is the second leading cause of death in the world. Cancer is a disease of the body's cells. Our bodies are always making new cells to replace worn-out cells or to heal damaged cells after an injury. Cancer begins when cells in a part of the body start to grow out of control. There are many types of cancer, but they all start because of out-of-control growth of abnormal cells (Rohini et al., 2013).

Natural products are considered effective anticancer agents and most of them are imitative from natural sources, including marine organisms, micro-organisms and plants (Cragg et al., 2005 and Newman et al., 2002). Natural products from plant origin like steroids, alkaloids and flavonoids received a great importance in the last years because of their pharmacological activities, including anticancer activity and antioxidant (Defeudis et al., 2003; Takeoka and Dao, 2003). The inhibition and scavenging radicals are important features of antioxidants that protect the human from infection and degenerative diseases.

Curcumin is the active component of turmeric (Curcuma longa). It is a polyphenolic compound extracted from roots of Curcuma species and has antitumor and antiinflammatory activities (Shishodia et al., 2003; Ammon and Wahl, 1990; Govindarajan, 1980). Different studies displayed that the dietary administration of curcumin powerfully suppressed the tumor formation in skin, duodenum, colon and forestomach of rodents (Huang et al., 1998; Rao et al., 1995 and Huang et al., 1994). Nagabushan and Bhide, (1992) declared in different studies that curcumin has an extensive anti-carcinogenic activity. Curcumin has also been shown to possess different pharmacological activities including anti-oxidant (Toda et al., 1985) and 
anti-cancer (Kuttan et al., 1985). Curcumin has the ability to inhibit carcinogenesis in vivo and in vitro at three stages; tumor promotion, angiogenesis, and tumor growth (Fadda et al., 2010).

Flaxseed which is a rich source of lignin both in vivo and in vitro; has been shown to be protective at the early promotion stage of carcinogenesis (Axyelon et al., 1982; Thompson et al., 1991). Great concentration of lignans is contained in flaxseed, it was mentioned that 12 to 1500 times of lignans found in flaxseed more than vegetables, nuts, grains and fruits (Meagher and Beecher, 2000). Consumption of foods rich in mammalian lignan precursors has been associated with reduced cancer risk (Rickard et al., 1999).

Ehrlich's ascites carcinoma (EAC) is an undifferentiated carcinoma. It has high transplantable ability, no regression, rapid propagation, short life span, $100 \%$ malignancy and does not have tumor-specific transplantation antigen (Ozaslan et al., 2011). EAC looks like human tumors and is used in many investigations as experimental model to study the antitumor effect of natural compounds and different drugs (Ferreira et al., 2007 and Silva et al., 2004). Ehrlich ascites carcinoma cells are transplantable tumors used in the investigation of anticancer drugs in mice (Agrawal et al., 2011). Several natural compounds have been stated to induce apoptosis in Ehrlich tumor cells in vivo and in vitro (Lawal et al., 2012).

The aim of this study is to evaluate the different anti-tumorigenic activities of curcumin and flaxseed against mice - bearing solid tumor induced with subcutaneous injection of Ehrlich Ascites Carcinoma (EAC) cells.

\section{MATERIALS AND METHODS:}

\section{Animals}

A total number of thirty two female mice weighing 20-25 gm were used in the experimental investigation of this study. The mice were obtained from the National Cancer Institute, Cairo University, Giza, Egypt. The mice were kept in the laboratory for one week before experimentation for acclimatization. Mice were housed in separate cages, fresh and clean drinking water was supplied Adlibitum. The experiments were accepted by the state authorities and it followed the Egyptian rules on animal protection, as well as specific local institutional laws for protection of animals under the supervision of authorized examiners.

\section{Tumor induction}

Ehrlich's ascites carcinoma is used as ascites or as a solid form (Ferreira et al., 2007). The Ehrlich's ascites carcinoma cell line was purchased from the Tumor Biology Department, National Cancer Institute, Cairo University (Giza, Egypt). The Ehrlich's ascites carcinoma cells were prepared under sterile conditions. The viability of the Ehrlich's ascites carcinoma cells was tested using Trypan blue dye exclusion technique (Lazarus et al., 1966). The experimental induction of solid tumor in female mice was carried out with subcutaneous injection of $0.2 \mathrm{ml}$ of Ehrlich ascites carcinoma containing $\left(3 \times 10^{6}\right.$ tumor cells) to the right hind limb of each mouse. The tumor developed and become palpable in all injected animals at 7-10 days post tumor inoculation.

\section{Extraction of Curcumin and Flaxseed}

Curcumin (Curcuma longa) and Flaxseed (Linum usitatissimum) were purchased from local markets, Cairo City, Egypt. A dried powder (10 g) from curcumin and (10 g) from flaxseed was mixed separately with $100 \mathrm{ml}$ organic solvent (ethanol, hexane and ethyl acetate). Each mixture was put at room temperature for $24 \mathrm{~h}$ on shaker with $150 \mathrm{rpm}$. Solution was filtered through muslin cloth and then re-filtered by passing through Whatman Filter No. 1. The filtrate which obtained was concentrated by complete evaporation of solvent at room temperature to produce the pure extract. Stock solutions of crude extracts for each type of organic solvent were prepared by mixing well the appropriate amount of dried extracts with respective solvent to obtain a final concentration of 100 $\mathrm{mg} / \mathrm{ml}$. Each solution was stored at $4^{\circ} \mathrm{C}$ after 
collecting in sterilized bottles until further use (Anamika, 2012 and Shahidi et al., 1994). Experimental design

This experimental study was classified into four groups; each group consists of eight mice; group (1): Control mice; group (2): Mice were injected subcutaneously with $0.2 \mathrm{ml}$ of Ehrlich ascites carcinoma (EAC) which contains $3 \times 10^{6}$ cells; group (3): Mice were inoculated with EAC as in group (2) then treated with curcumin extract in a dose $(50 \mathrm{mg} / \mathrm{kg}$ body weight) injected intraperitoneally three times weekly for four weeks; group (4): Mice were inoculated with EAC as in group (2) then treated with flaxseed extract in a dose (20 mg/kg body weight) injected intraperitoneally three times weekly for four weeks.

\section{In-vitro Cytotoxicity}

In-vitro cytotoxic activity was carried out using the Trypan Blue exclusion assay. The effective doses of curcumin $(6.25 \mu \mathrm{l} / 2 \mathrm{ml})$ and flaxseed (2.5 $\mathrm{\mu l} / 2 \mathrm{ml})$ were used. Three Eppendorf tubes; $1^{\text {st }}$ one contains $100 \mu$ l of EAC with a concentration of $10^{6}$ cells $/ \mathrm{ml}$ and phosphate buffer saline. The $2^{\text {nd }}$ contains a mixture of $100 \mu \mathrm{l}$ of EAC with a concentration of $10^{6} \mathrm{cells} / \mathrm{ml}$ and the effective concentration of curcumin and the $3^{\text {rd }}$ contains a mixture of $100 \mu \mathrm{l}$ of EAC with a concentration of $10^{6} \mathrm{cells} / \mathrm{ml}$ and the effective concentration of flaxseed. Incubate the Eppendorf tubes at $37^{\circ} \mathrm{C}$ for 3 hours and add $100 \mu$ of trypan blue to all test tubes; The EAC viability count was done using a Neubauer hemocytometer (Lawal et al., 2012).

Solid tumor volume

Antitumor effect of curcumin and flaxseed was estimated by the inhibition of tumor growth. Tumors were measured individually in each mouse using a Vernier caliper at 5 days intervals for one month starting with 15th day. Tumor volume was determined by the following formula: Tumor Volume $=$ length $\times$ width $^{2} \times 0.52$ (Jia et al., 2005).

\section{Biochemical studies}

Blood samples were collected from mice in different groups after 4 weeks of treatment. Sera were obtained by centrifugation of the blood sample and stored at $-20^{\circ} \mathrm{C}$ till evaluation the biochemical parameters. Serum activities of alanine aminotransferase ALT, aspartate aminotransferase AST, urine and creatinine was measures colorimetrically using test reagent kits (Mediserve Company; Egypt for liver enzymes and Randox; UK for kidney functions), according to the manufacturer's instructions.

Serum Malondialdehyde (MDA) was estimated by method of Jean (1983) at $530 \mathrm{~nm}$. Serum catalase activity was assayed by the method of Aebi (1984); the absorbance was measured at $420 \mathrm{~nm}$. Serum super oxide dismutase (SOD) activity was estimated by the method of (Marklund and Marklund, 1974); the absorbance was measured at $560 \mathrm{~nm}$.

\section{Histological examination}

Samples from the liver and kidneys were fixed in $10 \%$ neutral buffered formalin. Paraffin sections of $5 \mu$ thickness were prepared from all samples and were stained by haematoxylin and eosin (H\&E) and examined microscopically (Bancroft et al., 1996).

\section{Statistical analysis}

The results were expressed as mean \pm SD of different groups. The differences between the mean values were evaluated by one way analysis of variance ANOVA followed by Tukey-Kramer multiple comparison test (Armitage and Berry, 1987) using Graph Pad Prism software. $P$ values $<0.05$ were considered to be statistically significant. 


\section{RESULTS AND DISCUSSION}

\section{Tumor volumes:}

Estimation of the tumor volumes in EACbearing tumor, curcumin-tumor and flaxseedtumor mice; showed that the curcumin and flaxseed extracts inhibited the tumor volume in a very extremely significant manner $(P<$ 0.0001) (Table 1).

\section{Cytotoxic activity of extracts on EAC in vitro:}

Curcumin and flaxseed extracts induced highly mortality rates to EAC in vitro. The Ehrlich ascites carcinoma cells appear (not colored) with high viability rates as shown in (TumorUntreated) Fig.1 (A). On the other hand, Ehrlich ascites carcinoma cells treated with curcumin and flaxseed appeared colored with trypan blue. Mice-bearing EAC cells treated with curcumin and flaxseed showed a significant decrease in the total viable EAC cell count compared to non-treated tumor bearing animals. This is shown in Figs. (B) and (C) respectively.

Table (1): Effect of curcumin and flaxseed extracts on tumor volumes.

\begin{tabular}{|c|c|}
\hline Groups & $\begin{array}{c}\text { Tumor Volume }\left(\mathrm{mm}^{3}\right) \\
\text { Mean } \pm \text { SD }\end{array}$ \\
\hline Tumor untreated & $2.21 \pm 0.180278$ \\
\hline Tumor treated with curcumin & $1.226 \pm 0.15680^{* * * *}$ \\
\hline Tumor treated with flaxseed & $0.8600 \pm 0.1772^{* * * *}$ \\
\hline
\end{tabular}

(****) Very Extremely Significant $(\mathrm{p}<0.0001)$ compared to tumor untreated group.
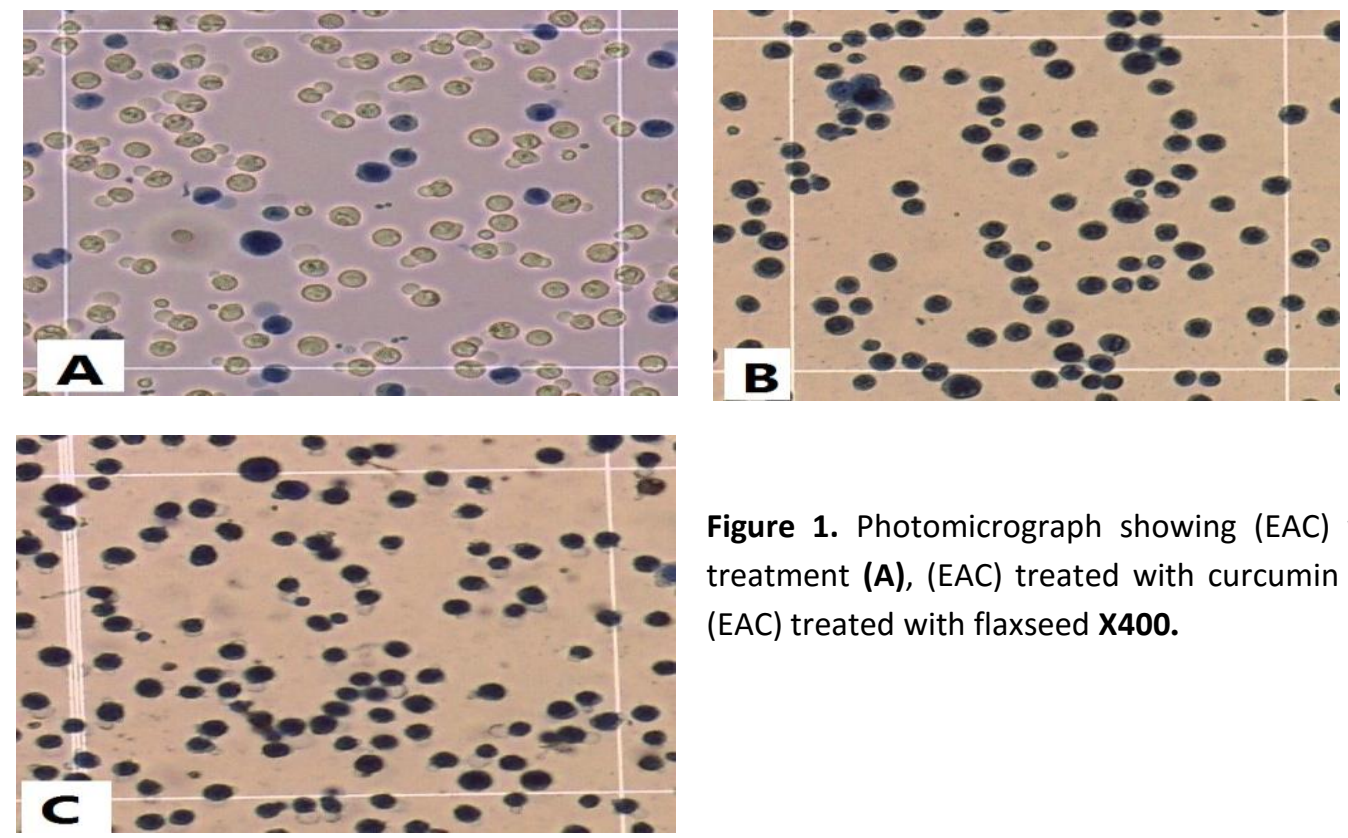

Figure 1. Photomicrograph showing (EAC) without treatment $(A),(E A C)$ treated with curcumin $(B)$ and (EAC) treated with flaxseed $\mathbf{X} \mathbf{4 0 0}$. 
Biochemical results:

Effects of curcumin and flaxseed extracts on liver \& kidney functions

Data in (table 2) revealed that the values of Alanine Transaminase (ALT) estimated in the mice blood sera; showed an elevated values in tumor group; very extremely significant ( $\mathrm{P} \leq$ 0.0001). Curcumin reduced the level of (ALT) to be only very significant $(P \leq 0.01)$ compared to normal values. On the other hand, the recorded values of (ALT) in tumor-flaxseed group is significant $(P \leq 0.05)$ compared to control values. The recorded values of Asparate Transaminase (AST) showed a very extremely significant in tumor group compared to control values ( $P \leq 0.0001)$. Curcumin and flaxseed extracts induced inhibition in the levels of (AST) to be as found in control group; this is obvious in (table 2).

Data in (table 2) showed also the effects of curcumin and flaxseed extracts on kidney functions (urea and creatinine) in mice bearing solid tumors. The recorded values of urea and creatinine showed an extremely significant change $(P \leq 0.001)$ and a very significant change $(P \leq 0.01)$ respectively when compared to normal values. Curcumin and flaxseed extracts modulated the values of urea and creatinine to record normal values without significant change compared to control.

Effect of curcumin and flaxseed extracts on oxidative and antioxidant enzymes

The recorded data in (table 3 ) revealed that the level of MAD in sera of mice -bearing solid tumors was increased in a very extremely significant $(P \leq 0.0001)$ change when compared to control. Curcumin extract decreased the level of MDA to record only a significant change $(P \leq 0.05)$ compared to normal values. On the other hand; flaxseed extract reduced the levels of MDA to be near of normal values without any significant change when compared to control.

Table (2): Effects of curcumin and flaxseed extracts on liver and kidney functions in different animal groups.

\begin{tabular}{|l|l|l|l|l|}
\hline Groups & ALT $(\mathbf{U} / \mathbf{L})$ & AST $(\mathbf{U} / \mathbf{L})$ & UREA $(\mathbf{m g} / \mathbf{d l})$ & Creatinine $(\mathbf{m g} / \mathbf{d l})$ \\
\hline Control & $15.67 \pm 0.5774$ & $16.00 \pm 2.000$ & $14.00 \pm 1.000$ & $0.4000 \pm 0.1000$ \\
\hline Tumor Untreated & $88.67 \pm 2.517^{* * * *}$ & $92.00 \pm 1.000^{* * * *}$ & $29.33 \pm 1.528^{* * *}$ & $0.8667 \pm 0.05774^{* *}$ \\
\hline Tumor + Curcumin & $20.00 \pm 1.00^{* *}$ & $21.00 \pm 2.646^{\$}$ & $16.00 \pm 1.000^{\$}$ & $0.4333 \pm 0.05774^{\$}$ \\
\hline Tumor + Flaxseed & $19.33 \pm 1.528^{*}$ & $19.33 \pm 0.5774^{\$}$ & $15.33 \pm 1.155^{\$}$ & $0.4667 \pm 0.05774^{\$}$ \\
\hline
\end{tabular}

Table (3): Effects of curcumin and flaxseed extracts on MDA, SOD and CAT activities in different groups.

\begin{tabular}{|l|l|l|l|}
\hline Groups & MDA $(\mathbf{n m o l} / \mathbf{g})$ & SOD $(\mathbf{U} / \mathbf{g})$ & CAT (U/g) \\
\hline Control & $4.045 \pm 0.005$ & $62.35 \pm 0.4041$ & $28.33 \pm 0.5774$ \\
\hline Tumor Untreated & $10.79 \pm 0.1493^{* * * *}$ & $30.56 \pm 0.8552^{* * * * *}$ & $11.33 \pm 1.528^{* * * * *}$ \\
\hline Tumor + Curcumin & $4.240 \pm 0.1114^{*}$ & $60.74 \pm 1.100^{\$}$ & $24.67 \pm 2.517^{\$}$ \\
\hline Tumor + Flaxseed & $4.181 \pm 0.1021^{\$}$ & $60.33 \pm 1.252^{\$}$ & $26.00 \pm 2.000^{\$}$ \\
\hline
\end{tabular}

All data are expressed as mean \pm SD.

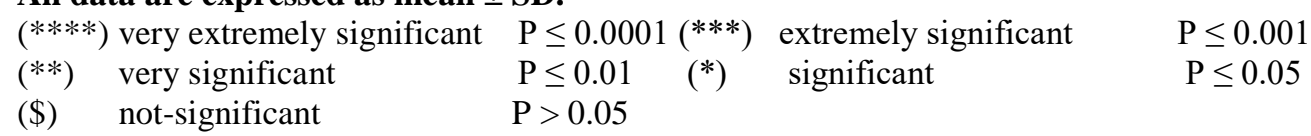


The values of the antioxidant enzymes (SOD and CAT) recorded also in (table 3 ) showed a very extremely significant reduction $(P \leq$ 0.0001 ) in sera of mice-bearing tumors. Curcumin and flaxseed extracts modulated the values of both enzymes to be elevated near to normal values without any significant change compared to control.

Histological results:

A- Liver
Sections of normal mouse liver stained with a hematoxylin and eosin (H\&E) technique showed the lobular structure of the mouse liver. Liver cells (hepatocytes) cells are arranged in plates or cords, and are seen radiating from the regions of central veins and spreading to the portal areas. The plates or cords of cells are separated by sinusoidal capillaries; this is shown in (Figure 2).

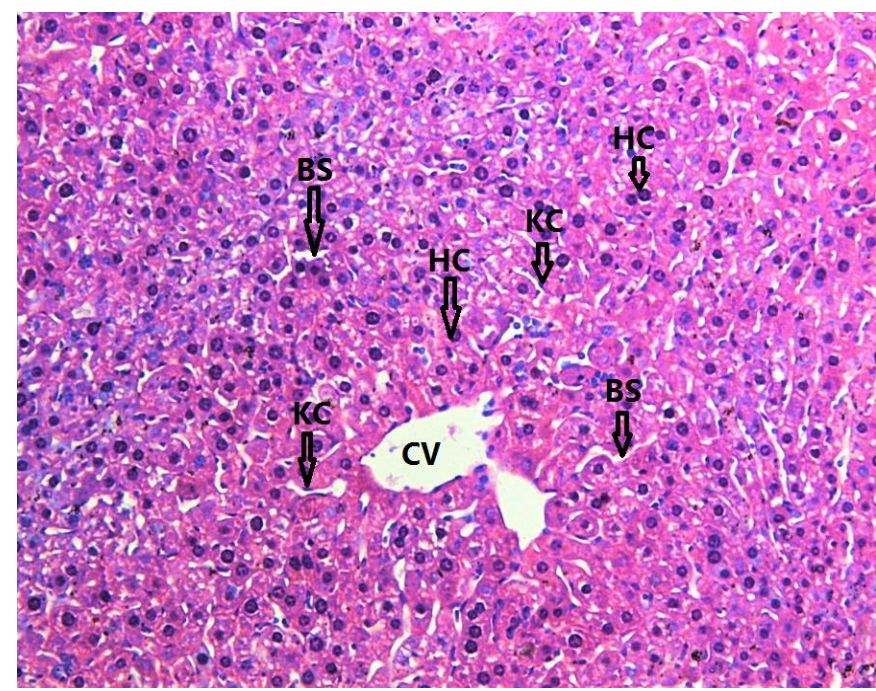

Figure 2. Photomicrograph of histological structure of control mouse liver; showing normal histological appearance of liver including central vein (CV), blood sinusoids (BS), hepatic cells (HC) and Kupffer cells (KC). H\&E, X400.

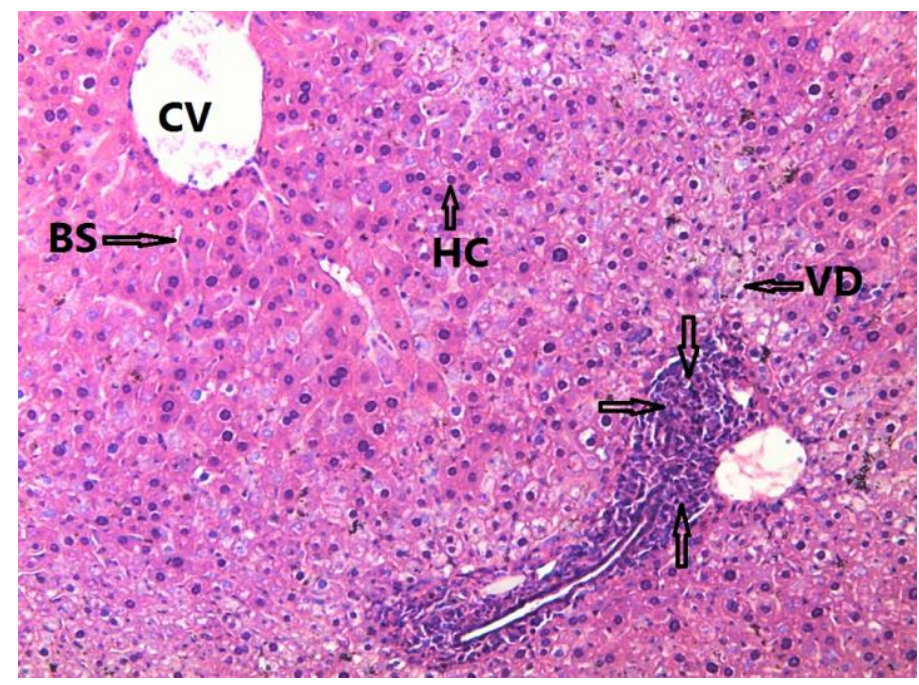

Figure 3. Photomicrograph of histological structure of liver in EAC tumor mouse; showing enlarged and mild congested central vein (CV), infiltration of tumor cells and leukocytes (arrows) and cytoplasmic vacuolar degeneration (VD). H\&E, X400. 


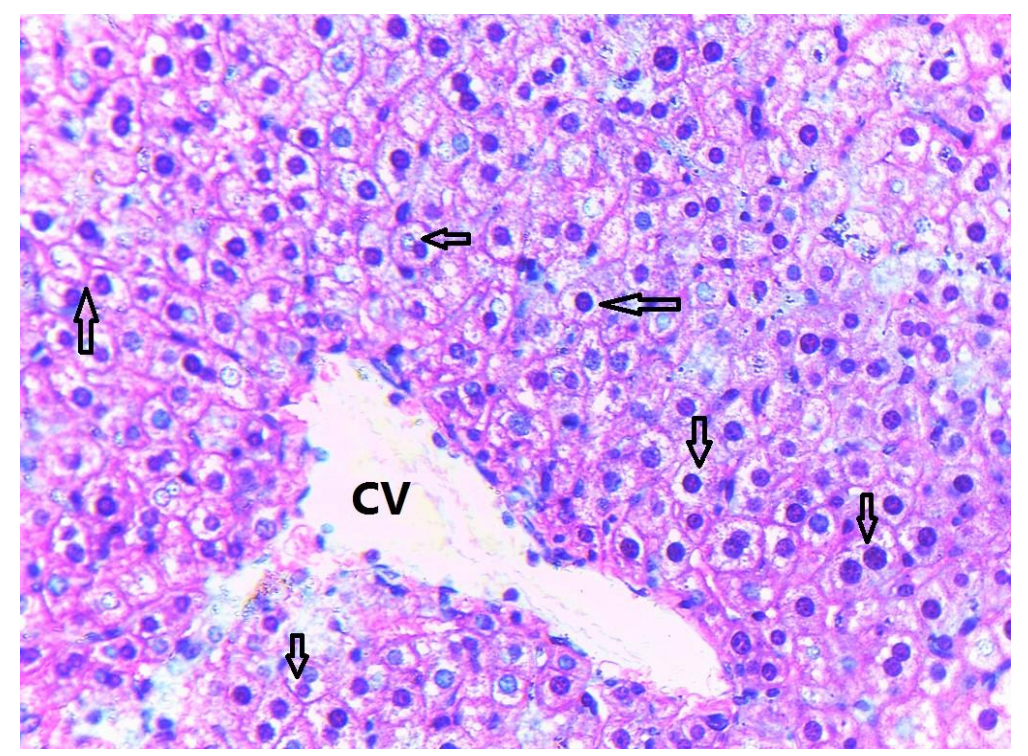

Figure 4. Photomicrograph of histological structure of liver in EAC tumor mouse; showing enlarged central vein (CV) and cytoplasmic vacuolar degeneration (VD) arrows. H\&E, X400.

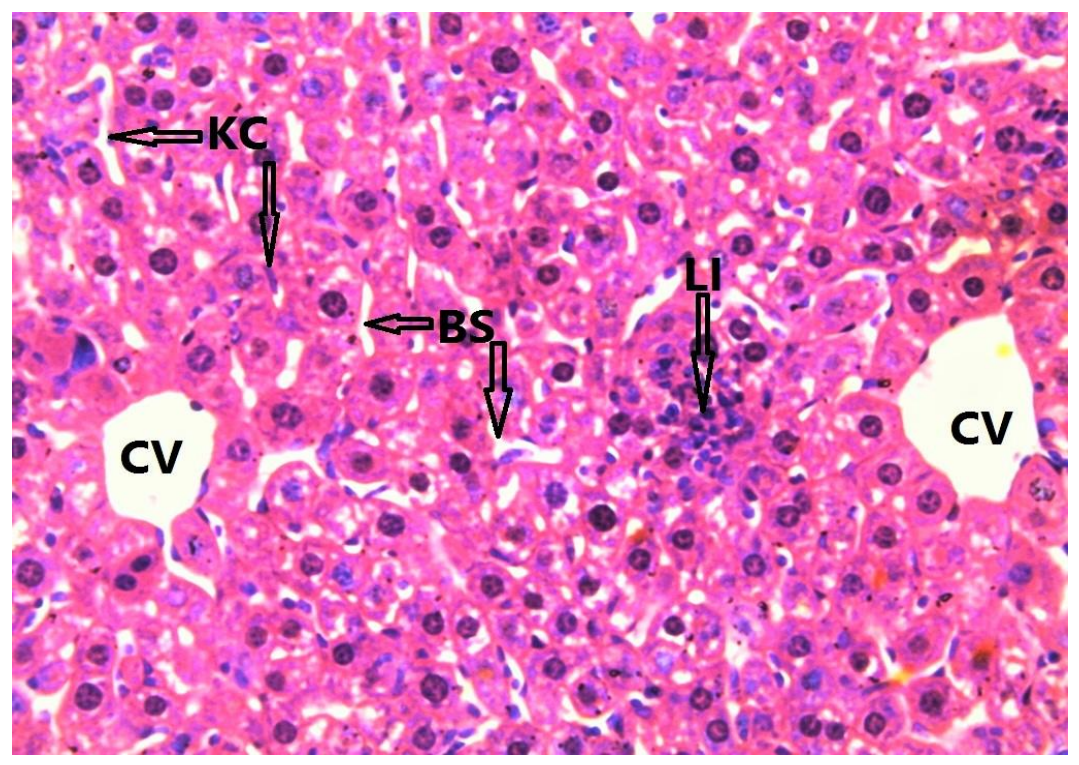

Figure 5. Photomicrograph of histological structure of liver in EAC tumor mouse treated with curcumin; showing some ameliorations in the hepatic structure; little leucocytic infiltration (LI) and abundance of kuffer cells (KC) are still found. H\&E, X400.

Curcumin and flaxseed extracts restored the normal histological structure of liver but some little histopathological effects are still found in localized leucocytic infiltration, abundance of Kupffer cells and congested central veins. This is obvious in (Figure $\mathbf{5}$ and Figure 6).

Different histopathological changes were observer in the liver of mice bearing solid tumors; enlarged and congested central vein, infiltration of tumor cells mixed with leukocytes, the blood sinusoid number decreased and little fatty degeneration of hepatic cells is obvious (Figure 3). Enlarged central vein and fatty degeneration of hepatic tissue is noticeable in (Figure 4). 


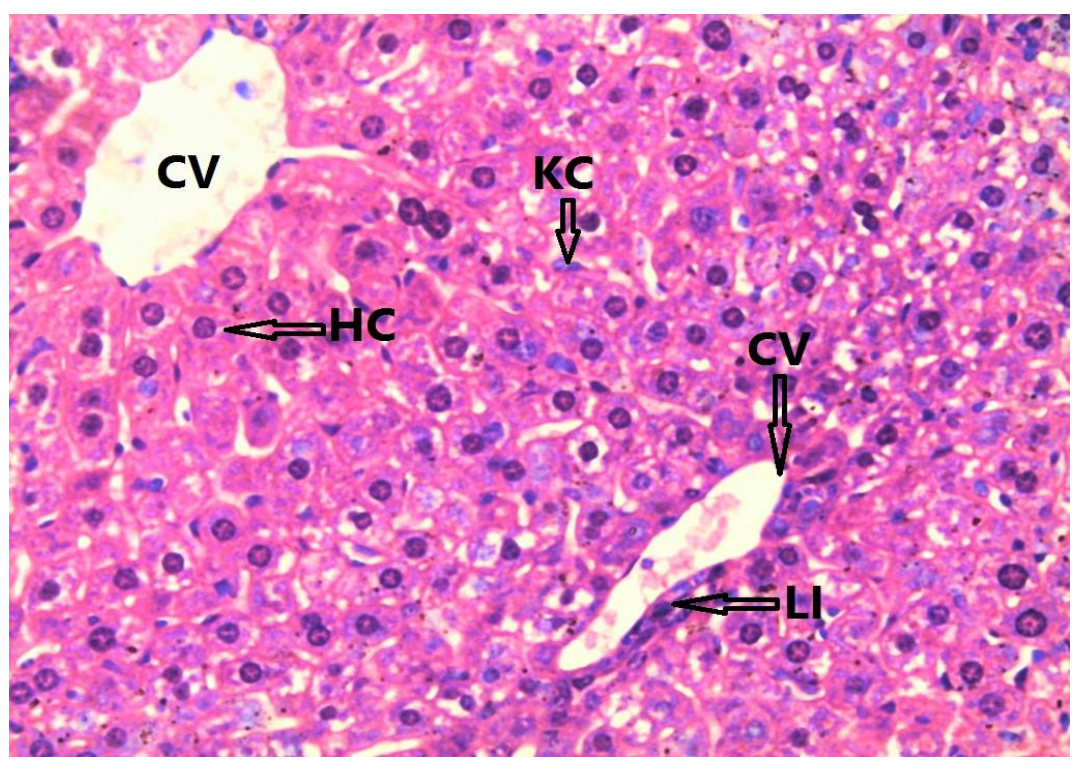

Figure 6. Photomicrograph of histological structure of liver in EAC tumor mouse treated with flaxseed; showing some ameliorations in the hepatic structure; little leucocytic infiltration (LI) and congested central vein (CV) are found. H\&E, X400.

\section{B- Kidney}

The control kidney is composed of two main regions; the renal cortex and medulla which possess normal histological features. The renal cortex enclosed by numerous renal corpuscles, each made up of a glomeruli and the Bowman's capsule. There is a characteristic normal space between the glomeruli and Bowman's capsule to allow renal filtration. The renal corpuscles are surrounded by proximal and distal convoluted tubules. The tubules have inner wide luminal space lined externally with cuboidal epithelium; this is represented in (Figure 7).

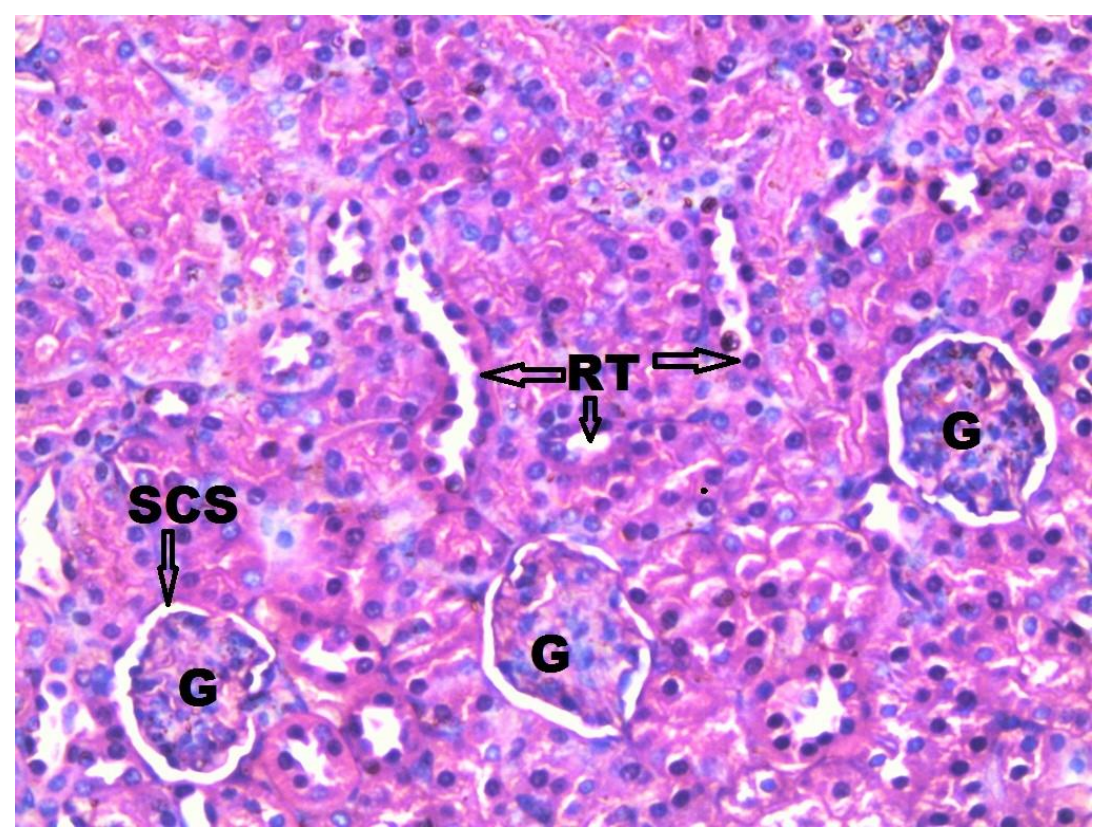

Figure 7. Photomicrograph of histological structure of kidney of a control mouse showing normal glomeruli (G) with normal sub-capsular space (SCS) and normal renal tubules (RT). H\&E, X400. 


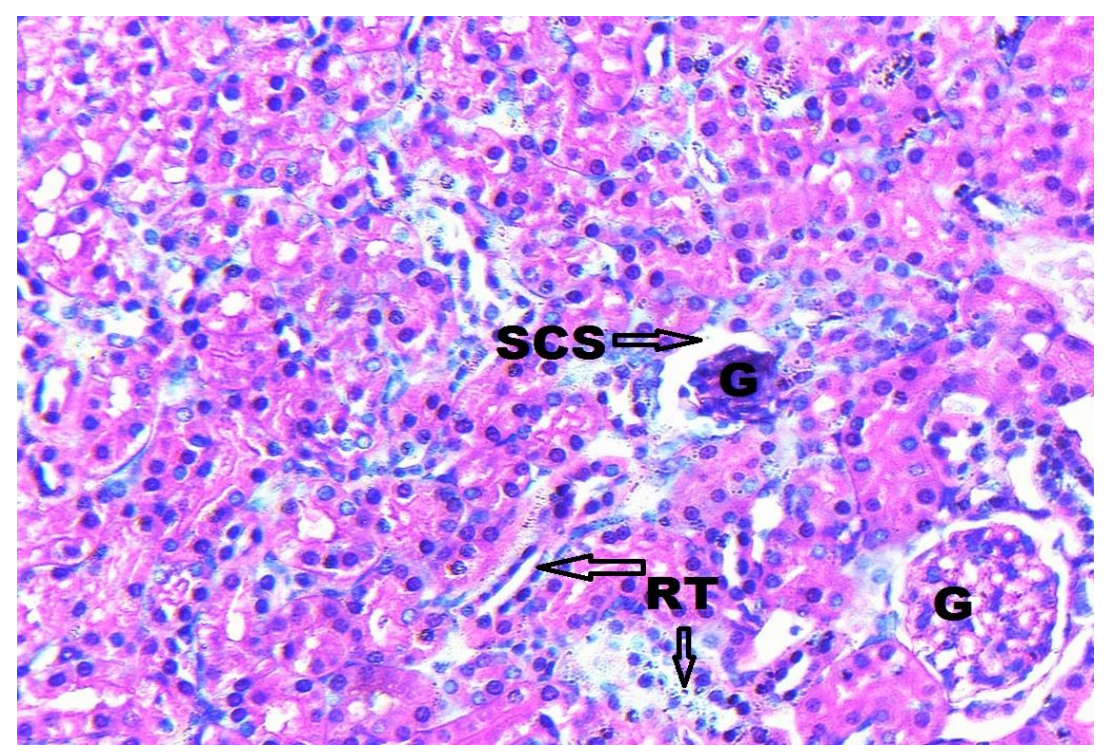

Figure 8. Photomicrograph of histological structure of kidney of a mouse bearing solid tumor showing enlarged sub-capsular space (SCS), degenerated renal tubules (RT) and degenerated glomeruli. H\&E, X400.

Mice treated with EAC revealed marked degeneration of the renal tissues; which are represented in degenerated glomeruli and renal tubules and the sub-capsular space (SCS) becomes enlarged; this is exhibited in (Figure 8).Curcumin and Flaxseed extracts induced different amelioration in the renal structure.
Most of the renal tubules and glomeruli appeared normal; sub-capsular space was enlarged in few glomeruli (Figure 9). This is also obvious in the renal structure of mice bearing solid tumor treated with flaxseed (Figure 10).

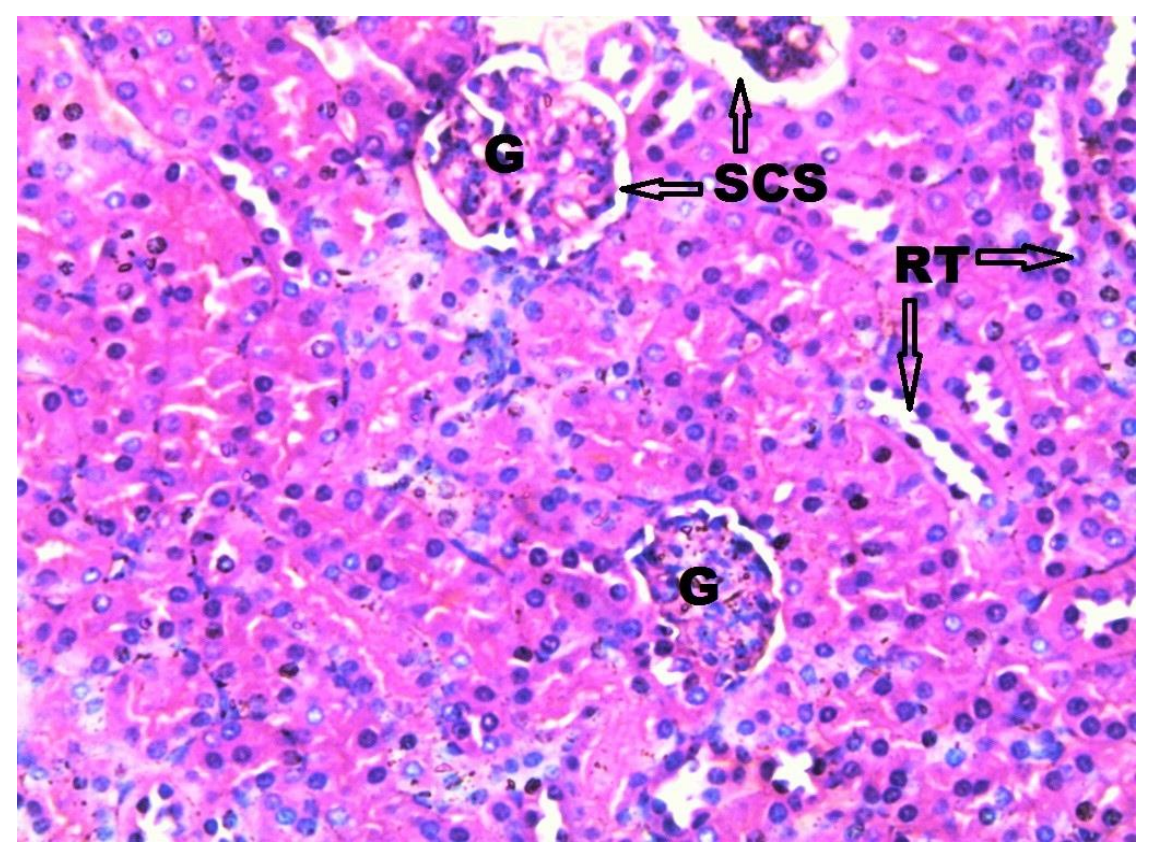

Figure 9. Photomicrograph of histological structure of kidney in a mouse bearing solid tumor treated with curcumin extract showing normal renal structure; glomeruli (G), sub-capsular space (SCS) and renal tubules (RT). H\&E, X400. 


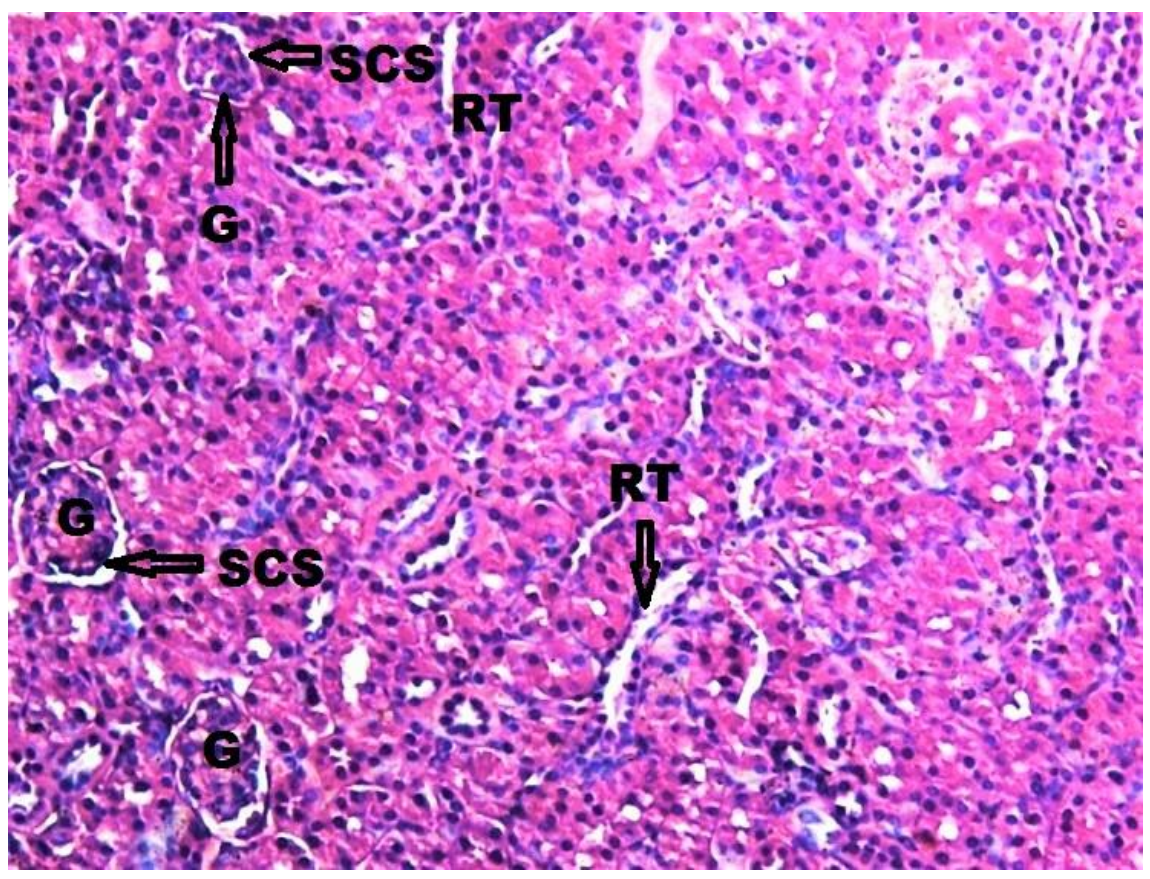

Figure 10. Photomicrograph of histological structure of kidney in a mouse bearing solid tumor treated with flaxseed extract showing normal renal structure; glomeruli (G), sub-capsular space (SCS) and renal tubules (RT). H\&E, $\mathbf{X} 400$.

Ehrlich Ascites Carcinoma (EAC) as a model in anti-cancer research was confirmed by many authors to give accurate and reliable results (Ramnath et al., 2002; Gupta et al., 2004). Ascites fluid is the direct nutritional source for the Ehrlich tumor cells. Thus, a rapid increase in ascites fluid with tumor growth would be a mean to give the nutritional obligation of tumor cells (Rajeshwar et al., 2005). The reduction in solid tumor volume showed that curcumin plays a direct part in killing the EAC tumor cells and improves the remedial effect of tumor chemotherapy. This result is in concomitance with (Chandru et al., 2007) who reported the same finding. Thompson et al. (1996), also decided the role of flaxseed in reducing the tumor volume. This result supports the results of this study. The tumor promotion and progression can be inhibited with curcumin (Huang et al., 1994 and Rao et al., 1995). The results of this work confirmed that curcumin reduced the ascites tumor growth and decreased the EAC tumor cell number without inducing any cytotoxic effects of normal cells. A variety of tumor cell types can be killed with curcumin in an apoptotic manner (Jiang et al., 1996).

The results of the in-vitro cytotoxicity assay revealed that the curcumin and flaxseed extracts are lethal to the EAC cells as there was an increase in the number of cells stained with trypan blue dye and this confirmed the high rates of mortality of EAC. This cytotoxic action might be due to mechanisms other than direct cytolytic effects such as directly on the tumor cells and cause their lysis and/or indirectly by destroying the microenvironment (Lawal et al., 2012). The result of this work is in an agreement with the previous finding.

Abdel Moneim et al. (2011), discussed that the liver enzymes such as ALT and AST are marker enzymes for liver function and safety. These enzymes are usually elevated in serum in mild hepatocellular injury and acute hepatotoxicity. This is the same in our study that the levels of liver enzymes increased in a significant manner in mice bearing EAC tumor cells. 
The data of this study which represented in tables (2\&3) revealed that a very highly significant increase in serum activities of (AST and $A L T$ ), urea, creatinine and serum MDA concentration were observed in tumor bearing female mice. On the other hand, a highly significant decrease in plasma catalase and SOD activities were detected in tumor bearing female mice during the experimental period as compared with control. Curcumin and flaxseed modulated the levels of ALT, AST, Urea, Creatinine, MDA, SOD and CAT to be near of normal values; these findings was confirmed with (Bhatia et al., 2007 and Abou Zaid et al., 2011).

Experimental Ehrlich ascites carcinoma revealed marked damage of liver and renal tissues (Abd El-Aziz et al., 2014). This is in concomitance with the results of this study which confirmed different histopathological changes induced in liver and kidney. In experimental Ehrlich ascites carcinoma treated with curcumin and flaxseed, the histological structure of the liver and the kidney appeared near to be normal as shown in figures $(5,6,9$ and 10). The antioxidant mechanism of curcumin includes scavenging of free radicals, interacting with oxidative cascade, oxygen switch off, inhibiting oxidative enzymes and chelating oxidative metal ions (Rukkumani et al., 2004). The chemopreventive effects of curcumin have been attributed to various biological properties, including neutralization of carcinogenic free radicals and antiangiogenesis action, which limits the blood supply to rapidly growing malignant cells (Chandru et al., 2007). Curcumin and flaxseed successfully restored liver function and architecture, normalized kidney functions and inhibited oxidative injury induced by EAC tumor cells. They also diminished the toxic effect of paracetamol on liver function and structure and restored the kidney functions.

\section{Conclusion:}

Ehrlich ascites carcinoma (EAC) has a powerful destructive effects on all investigated parameters; EAC induced increasing in the tumor volume significantly, increased the levels of liver function enzymes (ALT \& AST), kidney function (urea \& creatinine) and the oxidant enzyme Malondialdhyde (MAD) significantly. On the other hand, EAC reduced the levels of antioxidant enzymes Superoxide Dismutase (SOD) and Catalase (CAT) significantly and caused detrimental histopathological effects to the liver and kidney. Curcumin and Flaxseed extracts modulated the levels of (ALT, AST, urea, creatinine, MDA, SOD and CAT) significantly to be near of normal values in mice-bearing solid tumors. Curcumin and Flaxseed extracts also induced retrieval in the histological structures of both liver and kidney.

\section{References}

Abd El-Aziz A. F., M.E. Hefni and Amira M. Shalaby (2014): Inhibitory effects of Rosemary (Rosmarinus officinalis L.) on Ehrlich ascites carcinoma in mice. Int. J. Curr. Res. Aca. Rev.; 2(9):330-357.

Abdel Moneim AE, Dkhil MA, Al-Quraishy S. (2011): Studies on the effect of pomegranate (Punica granatum) juice and peel on liver and kidney in adult male rats. J Med Plants Res, 5:5083-5088.

Abei H (1984): Catalase in vitro. Methods Enzymol, 105:121-126.

Abou Zaid A.R. Omayma, Mohammed R.R. Hassanein, Yakout A. EL-Senosi, Mohammed F. EL-Shiekha (2011): AMELIORATIVE EFFECT OF CURCUMIN AND TANNIC ACID ON TUMOR-INDUCED IN FEMALE MICE. BENHA VETERINARY MEDICAL JOURNAL, 1:61-69.

Agrawal S.S., Sarita Saraswati, Rajani Mathur, Maneesha Pandey (2011): Antitumor properties of Boswellic acid against Ehrlich ascites cells bearing mouse. Food and Chemical Toxicology 49:1924-1934. 
Ammon, H.P.T. and Wahl, M.A. (1990): Pharmacology of Curcuma longa. Planta Med., 57, 1-7.

Anamika Bagchi (2012): Extraction of Curcumin. Journal of Environmental Science, Toxicology and Food Technology. 1(3): 1-16.

Armitage, P. \& Berry, G. (1987): In: Statistical Methods in Medical Research, Armitage, P. and Berry, G. (Eds.). pp. 186-00, Oxford: Blackwell Scientific Publications.

Axelson.M, Sjovall,J., Gustafsson.B.E., and Setchell.K.D.R. (1982): Origin of lignans in mammals and identification of a precursor from plants. Nature, 298, 659-660.

Bancroft J.P., Stevens A., Turner D.R. (1996): Theory and Practice of Histopathological Techniques, 4th Ed. Churchill Livingstone, New York.

Bhatia A. L., Avadhesh Sharma, Shikha Patni and Antim Lata Sharma (2007): Prophylactic Effect of Flaxseed Oil against Radiation-induced Hepatotoxicity in Mice. Phytother. Res. 21, 852-859.

Chandru H., A. C. Sharada, B. K. Bettadaiah, C. S. Ananda Kumar, K. S. Rangappa, Sunila and K. Jayashree (2007): In vivo growth inhibitory and anti-angiogenic effects of synthetic novel dienone cyclopropoxy curcumin analogs on mouse Ehrlich ascites tumor. Bioorganic \& Medicinal Chemistry 15:7696-7703.

Cragg GM, Kingston D and Newman DJ. (2005): Anticancer Agents from Natural Products. Brunner-Routledge Psychology Press, London, 186-205.

DeFeudis FV, Papadopoulos V and Drieu K. (2003): Gingko biloba extracts and cancer: a research area in its infancy. Fundam. Clin. Pharmacol. 17: 405- 17.

Fadda A. Ahmed, Farid A. Badria, Khaled M. El-Attar (2010): Synthesis and evaluation of curcumin analogues as cytotoxic agents. Med Chem Res; 19:413-430.
Ferreira E, da Silva AE, Serakides R, Gomes MG, Cassali GD (2007): Ehrlich tumor as model to study artificial hyperthyroidism influence on breast cancer. Pathol Res Pract 203: 39-44.

Govindarajan,V.S. (1980): Turmeric chemistry, technology and quality. CRC Rev. Food Sci. Nutr., 12, 199-301.

Gupta M, Mazumder UK, Sambath Kumar R, Sivakumar T, Mohan vamsi ML. (2004): Antitumor Activity and Antioxidant Status of Caesalpinia bonducella Against Ehrlich Ascites Carcinoma in Swiss Albino Mice. J. Pharmacol. Sci. 94: 177-184.

Huang, M.-T., Lou, Y.-R., Ma, W., Newmark, H.L., Reuhl, K.R. and Conney, A.H. (1994): Inhibitory effects of dietary curcumin on forestomach, duodenal and colon carcinogenesis in mice. Cancer Res., 54, 5841-5847.

Huang, M.-T., Newmark, H.H. and Frenkel, K. (1998): Inhibitory effects of curcumin on tumorigenesis in mice. J. Cell. Biochem. Suppl. 27:26-34.

Jean CD, Maryse T, Marie JF. (1983): Plasma Malondialdehyde levels during Myocardial infarction. Clinica Chimica Acta; 129: 319322.

Jia, L. - J., Xu, H. - M., Ma. D.- Y., Hu, Q.- G., Huang, X.- F., Jiang, W.- H., Li, S.- F., Jia, K.- Z., Huang, Q.- L. \& Hua, Z.- C. (2005): Enhanced Therapeutic Effect by Combination of Tumor-Targeting Salmonella and Endostatin in Murine Melanoma Model, Cancer Biol. Ther,4, 840-845.

Jiang M-C, Yang-Yen HF, and Yen JJ, Lin JK (1996): Curcumin induces apoptosis in immortalized NIH 3 T3 and malignant cancer cell lines. Nutr Cancer 26: 111-120.

Kuttan, R., Bhanumathy, P., Nirmala, K., George, M., (1985): Potential anticancer activity of turmeric (Curcuma longa). Cancer Lett. 129, 197-202. 
Lawal RA1, Ozaslan MD, Odesanmi OS, Karagoz ID, Kilic IH, Ebuehi OAT (2012): Cytotoxic and antiproliferative activity of Securidaca longepedunculata aqueous extract on Ehrlich ascites carcinoma cells in Swiss albino mice. International Journal of Applied Research in Natural Products Vol. 5 (4):19-27.

Lazarus H, Tegeler W, Mazzone HM, Leroy JG, Boone BA, et al. (1966): Determination of sensitivity of individual biopsy specimens to potential inhibitory agents: evaluation of some explant culture methods as assay systems. Cancer Chemother Rep 50: 543555.

Marklund S. and Marklund G. (1974): Involvement of the Superoxide Anion Radical in the Autoxidation of Pyrogallol and a Convenient Assay for Superoxide Dismutase. Eur. J. Biochem; 47:469-474.

Meagher, L. P.; Beecher, G. R. (2000): Assessment of data on the lignin content of foods. Journal of Food Composition and Analysis, v. 13, p. 935-947.

Nagabushan M, Bhide SV (1992): Curcumin as an inhibitor of cancer. JAm Cell Nutr 11:192-198.

\section{Newman DJ, Cragg GM and Snader KM.}

(2003): Natural products as a source of new drugs over the period 1981-2002. J. Nat. Prod. 66: 1022- 37.

Ozaslan M, Karagoz ID, Kilic IH, Guldur ME (2011): Ehrlich ascites carcinoma.African Journal of Biotechnology 10: 2375-2378.

Rajeshwar, Y., Gupta, M., Mazumder, U.K. (2005): Antitumor activity and in vivo antioxidant status of Mucuna pruriens (Fabaceae) seeds against Ehrlich ascites carcinoma in Swiss albino mice. Iranian J Pharmaco. Ther; 4:46-53.

Ramnath V., Kuttan G, Kuttan R. (2002): Antitumoureffect of abrin on transplanted tumours in mice. Indian J. Physiol. Pharmacol. 46: 69-77.
Rao, C.V., Rivenson, A., Simi, B. and Reddy, B.S. (1995): Inhibition of colon carcinogenesis by dietary curcumin, a naturally occurring plant phenolic compound. Cancer Res., 55, 259-266.

Rickard E. Sharon, Yvonne V. Yuan, Jianmin Chen, and Lilian U. Thompson (1999): Dose Effects of Flaxseed and Its Lignan on N-Methyl-N-Nitrosourea-Induced

Mammary Tumorigenesis in Rats. NUTRITION AND CANCER. 35(1), 50-57.

Rohini Ahuja, Neeraj Agrawal, Alok Mukerjee (2013): Evaluation of anticancer potential of Terminalia chebula Fruits against Ehrlich Ascites Carcinoma induced cancer in mice. Journal of Scientific and Innovative Research; 2 (3): 549-554.

Shahidi F., P.KJ.P.D. Wanasundara and R. Amarowicz (1994): Solvent extraction of flaxseed. Memorial University of Newfoundland St. John's, NF, Canada, AlB 3X9. Developments in Food Engineering: pp 621-623.

Shishodia, P., Potdar, C.G., Gairola, B.B. Aggarwal. (2003): Curcumin (diferuloylmethane) down-regulates cigarettesmoke-induced NF- kappa B activation through inhibition of Ikappa B alpha kinase in human lung epithelial cells: correlation with suppression of COX-2, MMP-9 and cyclin D1, Carcinogenesis 24: 1269-1279.

Rukkumani, R., Aruna, K., Varma, P.S., Rajasekaran, K.N., Menon, V.P., (2004): Comparative effects of curcumin and an analog of curcumin on alcohol and PUFA induced oxidative stress. J. Pharm. Pharmaceut. Sci. 7, 274-283.

Silva AE, Serakides R, Ferreira E, Moraes JR, Ocarino Nde $M$, et al. (2004): Effect of hypothyroidism on the solid form of Ehrlich tumor in intact or castrated adult female mice. Arq Bras Endocrinol Metabol 48: 867-874. 
Takeoka GR and Dao LT. (2003): Antioxidant constituent of almond [Prunus dulcis (Mill.) D.A. Webb.] Hulls. J. Agric. Food Chem. 51: 496-501.

Thompson L. U., Sharon E. Rickard, Lindy J. Orcheson and Maja M. Seid (1996): Flaxseed and its lignan and oil components reduce mammary tumor growth at a late stage of carcinogenesis. Carcinogenesis vol.17 no.6 pp. 1373-1376.
Thompson, L. U., Robb. P., Serraino.M. and Cheung.F. (1991): Mammalian lignan production from various foods. Nutr. Cancer, 16, 43-52.

Toda, S., Miyase, T., Arichi, H., Tanizawa, H., Takino, Y., (1985): Natural antioxidants. III. Antioxidative components isolated from rhizome of Curcuma longa L. Chem. Pharm.Bull. 33, 1725-1728. 